\title{
CANNED: THE RISE AND FALL OF CONSUMER CONFIDENCE IN THE AMERICAN FOOD INDUSTRY, BY ANNA ZEIDE, A BOOK REVIEW
}

\author{
Milena Ilić1, Marko Rankovićn ${ }^{2}$ Lazar Janic ${ }^{3}$ \\ *Corresponding authorE-mail:milena.ilic@its.edu.rs
}

\begin{abstract}
A R T I C LE I N F O
Book review

Received: 19 August 2019

Accepted: 13 September 2019

doi:10.5937/ekoPolj1903905I

UDC 664.8/.9:366.14(73)
\end{abstract}

\section{Keywords:}

food industry, consumers, packaged food, canning industry

JEL: Q18, I15

\section{A B S T R A C T}

The paper prepared in the form of a book review is a review of the book written by Anna Zeide, assistant professor of Professional Practice at Oklahoma State University, entitled: Canned: The Rise and Fall of Consumer Confidence in the American Food Industry, published in 2018. The book is a part of the California Studies in Food and Culture Series of the publisher University of California Press, and is the winner of the James Beard Award for Reference, History \& Scholarship for the year 2019, which is delivered by the James Beard Foundation, which has been promoting the food industry in the United States of America for already 30 years now, through scientific-research work, the development of the industry itself, the development of female leadership and leadership in general, as well as through other programs (James Beard Foundation, 2019).

(C) 2019 EA. All rights reserved.

\section{Introduction}

Anna Zeide, the authoress, a professor of Oklahoma State University, a food historian, is one of the most significant representatives of this academic discipline in the world. Her book, entitled: Canned: The Rise and Fall of Consumer Confidence in the American

1 Milena Ilić, Ph.D., Assistant Professor, University Business Academy in Novi Sad. Faculty of Contemporary Arts, Belgrade, Svetozara Miletića 12, 11000 Belgrade, Serbia, and Information Technology School, Belgrade, Comtrade Technology Center, Savski nasip 7, 11070 New Belgrade, Serbia, Phone: +381 605522 581, e-mail: milena.ilic@fsu.edu.rs and milena.ilic@its.edu.rs, ORCID ID: https://orcid.org/0000-0002-9719-175X

2 Marko Ranković, Ph.D., Assistant Professor, Fakultet za informacione tehnologije i inženjerstvo Jurija Gagarina 149a, 11070 New Belgrade, Serbia and Information Technology School, Belgrade, Comtrade Technology Center, Savski nasip 7, 11070 New Belgrade, Serbia, Phone: +38163 682816, e- mail: marko.rankovic@fiti.edu.rs and marko.rankovic@ its.edu.rs, ORCID ID: http://orcid.org/0000-0002-3479-8431

3 Lazar Janić, Ph.D., Professor of Vocational Studies, College of Health Vocational Studies in Belgrade, Cara Dušana 254, 11080 Zemun, Serbia, Phone: +381 6389312 93, e-mail: lazarjanic@gmail.com, ORCID ID: https://orcid.org/0000-0002-8766-9430 
Food Industry, which was published by the University of California Press in 2018, is the subject matter of the research conducted in this scientific article. (Zeide, 2018).

Within the framework of the part entitled 'The Goal of the Paper and the Methodology Used', the academic, i.e. scientific goal of this review, as well as the methodology which will be used, will be presented.

Within the framework of the part entitled 'The Paper Results with Discussion', the structure of the book will be presented per chapters and an analysis of its content will be carried out by applying the stated scientific methodology.

The conclusive considerations, as well as the stated references, will be given at the end of the presentation.

The book systematically shows the development of canned food in the United States of America, analyzing the historical context of its first steps 150 years ago, in the time of the earliest beginnings of the food industry and in the time when the Americans had trust in packaged food, as the author herself judges this period.

\section{The Goal of the Paper and the Methodology Used}

The goal of the paper (the book review) is to objectively present the book by the authoress Anna Zeide, Assistant Professor of Professional Practice at Oklahoma State University, entitled: Canned: The Rise and Fall of Consumer Confidence in the American Food Industry, published in 2018, through the presentation of the structure of the book, the references and the other sources used, and the content analysis. Through the book review, both scientific and social influences of the book are also perceived. The methods characteristic of social sciences, such as the historical method, a case study analysis, deduction and induction, will be used for the research. The paper has been written based on the secondary research done by the authors.

\section{The Paper Results with Discussion}

The book entitled Canned: The Rise and Fall of Consumer Confidence in the American Food Industry, by the authoress Anna Zeide, published in 2018, is published both in its paper and in its electronic editions. It has 280 pages, and for her research study, the authoress used and cited the references and the selected bibliography from archives and libraries specialized in agriculture, the food industry, the medical and historical area, as well as those of a general type, such as: California State Archives, Sacramento, CA; College of Agriculture and Life Sciences at Stanford University Medical Center, Palo Alto, CA; Grocery Manufacturers Association Library. National Canners Association Archives. Washington, DC; National Archives and Records Administration, National Archives at College Park, College Park, MD; Wisconsin Historical Society Archives, University of Wisconsin-Madison. She also used periodicals, such as: American Food Journal, Canner, Canner/Packer, Processed Prepared Food, Canning Age, Chicago Tribune, Journal of Marketing, Los Angeles Times, Market Growers Journal, New York Times, Western 
Canner Packer, Wisconsin Canners Bulletin and Wisconsin Farmer. Formal references include more than 150 different print sources dating from 1812. (Appert, 1812)

The book is structured into six main chapters, which follow after the introductory chapter, which are added to by the conclusion and the auxiliary segments (Acknowledgments, Notes, Selected Bibliography and Index). These six chapters present the best-known events in the history of the food industry of America from its early beginnings to the contemporary era.

The six chapters in the book treat the two periods in the history of the canning industry in the USA. The first period encompasses the years from the 1800 s to the 1930s, which the authoress considers to have represented a consumer-driven culture to canning companies. In this period, companies financed assets in order to stimulate the development of regulation and research in the field of food safety by attracting their consumers' trust in this way.

The second period, which relates to the 1930s and has been lasting to date, is marked by the efforts of the canning industry to also attract consumer trust, but this way implies using psychology and marketing, i.e. with the help of advertising, branding as the primary form, whereas research studies on products safety are less important to them, and the very awareness of that fact indicates the problem of the transparency of the business operations carried out by these companies.

Race and class issues are important for assumptions and decisions that people make. In one stage of its history, especially in the white-oriented middle class, canned food has a social context in terms of affordable food for those who cannot afford to be "foody" (a metaphor).

Within the framework of the first chapter, entitled "Condensed Milk: The Development of the Early Canning Industry", the authoress presents the food industry in America, i.e. the canning industry and its early beginnings. Within the framework of this chapter, the authoress presents her knowledge that arose from numerous archival and libraryresources starting from 1795. The chapter begins with an illustration of the events dating back in 1864 and the letter of a soldier who fought in the Civil War, who had "written it on the back of a label peeled from a can of Borden's Condensed Milk" (p. 1) (Wisconsin Historical Society, Madison).

Within the framework of the second chapter, entitled "Growing a Better Pea: Canners, Farmers, and Agricultural Scientists in the 1910s and 1920s", the authoress emphasizes the role of agricultural scientists in the promotion of the products of the canning industry. The canning industry developed a broad network in cooperation with scientists, with the help of the law and the media so as to attract consumers, and the final effect the more recent history has also given rise to a change in the nutrition system of the Americans based on processed food.

Within the framework of the third chapter, entitled "Poisoned Olives: Consumer Fear and Expert Collaboration", the authoress presents a case from 1919 and 1920, when botulism in canned olives appeared, and the death of the 18 people who had consumed 
those olives. She presents the answer from the industry that became aware of the weakness in the system by establishing the Botulism Commission of Scientific Experts, with the aim of creating the olive production safety process and the processing that could ensure no similar crisis in the future, also taking the other measures whose effect reflected in the creation of a network of the owners of canner enterprises, scientists and the representatives of the System who were shaping the food system in America.

Within the framework of the fourth chapter, entitled "Grade A Tomatoes: Labeling Debates and Consumers in the New Deal", the authoress deals with transparency issues. She presents a lack of information about the quality of products and the nutritional features of the same canning companies that were creating loyalty to a brand, simultaneously promoting the companies themselves. The authoress presents the process of the selection of tomatoes for canning, the checking of their quality, the grading and so forth, the stages within the framework of which the grower, the agricultural scientist, the canner and other persons were involved, of which, however, consumers had no knowledge at all given the fact that no pieces of information were displayed on the labels of such tomato cans; so, at the begging of the 1930s, that needed to be changed by consumer advocacy and government representatives. (p. 122) The New Deal measures awoke consumers themselves, too, not only the American economy. As a reformer and the creator of the New Deal measures, Kainz writes in his work entitled "The End of Laissez-Fair" that it is not true that the God-gifted "natural freedom" in economic activities does not belong to individual persons. He wanted to point to the fact that the world is not so ordered that an individual's personal and social interests are always in compliance with each other, and that it is not true, either, that an interest has become recognized since it is frequently the case that the individual persons who aspire to goals are insufficiently informed or are too weak to achieve them. (Ilić, 2017) The authoress pointed out that many of the agencies that had been created by the New Deal had had the sections dealing with consumers' interests. (p. 125)

Within the framework of the fifth chapter, entitled "Fighting for Safe Tuna: Postwar Challenges to Processed Food", the authoress presents the case of the appearance of botulism in 1963 in tuna cans, from which several people died; however, differently from the situation in the past when scientists had been engaged in the development of safe processing processes and food canning, the accent was no placed on the promotion of tuna on a wide front so as to forget about the problem, or ignore it.

Within the framework of the sixth chapter, entitled "BPA in Campbell's Soup: New Threats to an Entrenched Food System", the authoress presents the case mentioned in the title of the chapter, and highlights the link between Bisphenol A used for the majority of canned food and ADHD, cancer and reproductive disorders. Newer research, as one conduced in Tecnologico Nacional de Mexico finds connection of canned food and cancer cells regarding the fact that common beans (Phaseolus vulgaris L.) processed by canning, contain phenolic compounds with the ability to inhibit the proliferation of CRC cells. (Moreno-Jiménez et all, 2019) 
The authoress presents the canning industry in the United States of America, i.e. its development in terms of the use of technology, leading manufacturers' strategies and marketing, starting from consumers' original trust, later followed by their great resistance that was present during the contemporary period of the development of the industry, and the current moment. The authoress presents the role of different interested parties, i.e. trade groups, and also indicates the role of political lobbying and public relations in the marketing of canned food.

The book is inspired by the attitude that what people consume and the manner in which they process and consume food gives a shape to the quality of life and the social contexts coexisted by people. As the academic discipline the authoress primarily deals with as her expertise, the history of food has also been built on by the other scientific disciplines from within the field of social-humanist sciences, as well as technical sciences, in the writing of this book, which proves the breadth of the subject matter of the research and a potential scientific and social significance of the book. If the scope of the book is perceived, it is also possible to notice one deeper social dimension that is indicative of the effect of the availability of no seasonal food and the food not grown in the same locality in which its consumers live on the lives of these consumers. With respect to the presentation of the market of the food industry, the authoress has perceived the supply chain from small manufacturers to industrial mass manufacturing, drawing a parallel between the two chains and emphasizing the differences between a jar containing a product manufactured by an individual manufacturer with a label providing full information and an insight into the origin of the product and its quality and identifies the manufacturer and the values the product carries with itself, on the one hand, and cans containing food that brings another metaphor, on the other. The canned food produced by industrial manufacturers sends different messages and brings with itself messages related to a different cultivation, packaging, distribution, and promotion, which also requires a specific "window" which would enable consumers to gain an insight into the essence of manufacturing.

The whole project is the identification of the overall industry and the demystification of the seemingly easy choice made by consumers every day and the purchase decisions they make, behind which, however, there are different propaganda messages, promotional contents, a political context and the other contents thanks to which the positioning and repositioning of different ideas and brands in the consumer's consciousness are performed, the development of different attitudes towards the origin of the goods, the quality and so on, yet even the attitudes of the ethnocentricity of consumers with respect to the values forgotten by consumers while using convenience food like "ethnic identity, value of family togetherness, reflection, and diversity conveyed by home-cooked food, traditional recipes, and shared meals". In this part of the book, the authoress states the attitudes of the editor of Food for People, Not for Profit (and agrees upon them) that the essence of the health and political problems advocated by consumers are, in fact, a more fundamental criticism of the dietary culture promoted by the processed-food industry. (Lerza, Jacobson,1975) 
Regarding American processed-food industry, findings of a study conducted in 2017 shows that persistence of profit in food processing in USA as well in EU is lower than in other manufacturing sectors. (Gschwandtner, Hirsch, 2018)

The papers dealing with the ethnocentricity of consumers indicate the fact that this concept relates to the people who find their group to be the center of the world, who interpret everything within the perspective of their own group, rejecting all those who are not similar to them from a cultural standpoint and accepting unreservedly those who are similar to them from a cultural standpoint. (Rakić, Rakić, Stanojević, 2019) Similarly to the authors Šapić, Furtula, Durkalić, the authoress highlights the fact that the western-styled culture is characteristic for its efficient manufacturing, whereas the southern-styled culture of food is determined by hedonism and a specific consumption, for which reason it is traditionally liaised with the local cultivation of the product. (Šapić, Furtula, Durkalić, 2018)

The scientists in the fields of biology and chemistry, i.e. the field of natural sciences, who had worked in the past, whose research studies had been financed by the canned food manufacturers, were replaced with scientists working in the field of social sciences, with the intention to ensure a stronger position of canned food in American society. Different sociologists, marketers and psychologists, as well as political lobbyists, are included in the network with canners and officials, so that consumers could be more familiar with buying canned food. In one period, through changing the relations of consumers, the industry and representatives of regulatory bodies, these sides in the dialogue took even different positions. At one point in time, canners were 'for' anti-regulatory processes, as well as 'for' consumer advocacy, considering them to be Canners, which were opting for an anti-regulatory processes, as well as consumer advocacy, considering them as an unnecessary and limitative for food industry.

A study conducted by Lerro and associates, in 2018, regarding preferences for corporate social responsibility in the food industry find that there are five consumers' groups: 'environmentalists', 'pro-socials', 'collectivists', 'animal friends' and 'selfish health centered'. His study shows that consumers are willing to pay more to reward food companies that are socially responsible. (Lerro et all, 2018)

The authoress emphasizes the role of the state regulatory bodies in the regulation of the food and canned industry in America, and the support of the nongovernment sector, i.e. of different consumers' associations and agencies for health promotion. She also presents a pronounced interest of and the doubt of some consumer niches in the transparency of the business operations carried out by the food industry, the work of the federal subsidies for agriculture, and the intentions and influences of the industry on environmental health, the impact on climate change, as well as the alternative ways of eating, the consumer growing interest in the origin of products and their quality. The authoress also highlights the individual and collective transformation of the consumer attitudes that may lead to a change in the food system in the long run since broader scopes are necessary. Different examples show that there are quite a lot of things that the 
individual consumer has no knowledge of and cannot control, so that there is a critical need for broader forces in the reshaping of the food industry and food justice activists also have their role in this process, beside the individual consumer. Behind the ongoing changes lie billions of decisions made by individual consumers that may change the food issues and the political system. It is important that individual consumers should think about where a food comes from and create a critical mass in order to make a systemic change. Also, collective consumers can be introduced and educative programs can be established so as to make a broader effect.

\section{Conclusions}

The historical analysis performed by the authoress starts with the phenomena of canned milk, moving on to the fallout of the processed food industry in America, represented by the presence of the bisphenol A chemical (BPA) in a tomato soup. The authoress demystifies what the canned food industry owes its success to, by presenting the examples from science, technology and politics that altered the course of the consumer behavior towards canned food. The authoress points out the fact that canning, as a segment of the food industry in America, has a great impact on the American business history, as well as its food systems, and a significant importance to consumers.

The book shows the pathway canned food passed and how it shaped the American lifestyle and became a part of the subculture. The complex presentations are also inclusive of agricultural manufacturing, agro-business, the economy, marketing, biochemistry, and nutrition science so as to make the ambience presentation complete and create a holistic approach to the analysis of the food industry (the canning industry in particular) in America.

The book engages various topics concerning the broad scientific aim and scope, and forces the authoress to involve herself in studying business, technology, history, and sociology so that she could completely perceive the effects that canning has on American society.

\section{Conflict of interests}

The authors declare no conflict of interest.

\section{References}

1. Gschwandtner, A. and Hirsch, S. (2018), What Drives Firm Profitability? A Comparison of the US and EU Food Processing Industry. The Manchester School, 86: 390-416. doi:10.1111/manc.12201

2. Ilić, M, (2017). Osnove ekonomije, finansija i računovodstva. Visoka škola strukovnih studija za informacione tehnologije, ITS - Beograd. [In English: Ilic, M, (2017). Fundamentals of Economics, Finance and Accounting. College of Professional Studies in Information Technology, ITS - Belgrade] 
3. James Beard foundation https://www.jamesbeard.org/blog/the-2019-james-beardmedia-award-winners (July, 30.2019.)

4. Lerza C, Jacobson M. (1975). Food for People, Not for Profit: A Source Book on the Food Crisis. Ballantine Books

5. Lerro, M, Vecchio, R, Caracciolo, F, Pascucci, S, Cembalo, L. (2018). Consumers' heterogeneous preferences for corporate social responsibility in the food industry. Corp Soc Resp Env Ma.25: 1050- 1061. https://doi.org/10.1002/csr.1519

6. Moreno-Jiménez, MR, López-Barraza, R, Cervantes-Cardoza, V, (2019). Mechanisms associated to apoptosis of cancer cells by phenolic extracts from two canned common beans varieties (Phaseolus vulgaris L.). J Food Biochem; 43:e12680. https://doi.org/10.1111/jfbc. 12680

7. Nicolas, A. (1812) The Art of Preserving All Kinds of Animal and Vegetable Substances for Several Years: A Work Published by Order of the French Minister of the Interior, on the Report of the Board of Arts and Manufactures. 2nd ed. London: Black, Perry and Kingsbury

8. Rakić M, Rakić B, Stanojević Lj. (2019). Encouraging consumer ethnocentrism in the function of domestic foodstuffs consumption, Economics of Agriculture, 66 (2), 341-355. doi:10.5937/ekoPolj1902341R

9. Šapić S, Furtula S, Durkalić D. (2018). Prestige and national identity as predictors of food products purchase. Economics of Agriculture, 65 (2), 643-657. doi:10.5937/ ekoPolj1802643S

10. University of California Press https://www.ucpress.edu/book/9780520322769/ canned (July 30, 2019.)

11. Zeide, A, (2018). Canned: The rise and fall of consumer confidence in the American food industry. University of California Press 